ISSN 2075-471X

www.mdpi.com/journal/laws/

Article

\title{
The Political Potential of the Return Directive
}

\section{Andrew Crosby}

Fonds National de Recherche Scientifique (FNRS), Group for Research on Ethnic Relations, Migration \& Equality (GERME), Department of Sociology, Université libre de Bruxelles (ULB), Brussels 1050, Belgium; E-Mail: acrosby@vub.ac.be

Received: 23 November 2013; in revised form: 20 January 2014 / Accepted: 22 January 2014 / Published: 27 January 2014

\begin{abstract}
This paper demonstrates how the legitimate interests of immigrants are gradually being recognized through judicial application of EU immigration law. A philosophical and theoretical introduction demonstrates how this recognition constitutes a political momentum. After a brief review of the impact of the ECtHR, we discuss the case law of the ECJEU on the Return Directive to show how, through the principles of proportionality and sincere cooperation, this legitimate interest is indirectly being calculated by the Luxembourg court. This means that national courts will have to follow suite, as is demonstrated in the last section of this paper. Hence the title of the article: the political potential is due to this indirect recognition. In the conclusion, a suggestion is made to further develop this potential.
\end{abstract}

Keywords: part without part; normal migrants; human rights; Return Directive; proportionality; detention; immigration

\section{Theoretical Background}

\subsection{La Mésentente_Jacques Rancière’s Political Philosophy}

Five elements constitute Rancière's political philosophy: the idea of a 'part without part' in society, the notions of disagreement, injustice, police and of politics.

According to Rancière the Ancient Greek identify the beginning of the (political) community with the recognition (or counting) of the different parts of society and their share therein-that is, their value as well as their contribution to it. Thus, the common power should be distributed according to each part's share. Yet, this is but an ideal representation of the good community as it lies in stark contradiction with the empirical observation of things. In fact, this counting of the parts may conceal a 
fundamental miscount-one which does injustice to one (or more) of the parts ([1], pp. 24-25). Rancière then explains this with the aid of Aristotle's three shares (axiaï) of each part: "the wealth of the smallest number (oligoi), the virtue or excellence (aretê) from which the best (aristoï) derive their name, and the freedom (eleutheria) that belongs to the people (demos) ([2], p. 6).”

To each title corresponds a particular regime-oligarchy of the wealthy, aristocracy of the virtuous and democracy of the people-and their balance (leaving aside the question of achieving it) produces the common good. However, this balance is challenged by the fact that whereas the entitlements of the rich and the good are somehow concrete qualities (wealth and virtue), the freedom of the people is but a negative, empty property that limits the right of the former two parts over the third. This limitation originated in the abolishment of enslavement for debt meaning that no man born in Athens could be enslaved. Hence, all men were part of the people partaking in community matters. As such, they were regarded as equals of the wealthy and virtuous, who were also free, but remained superior to the former in every aspect. In other words, the people, though formally equal, were still inferior to and ruled by the wealthy and the virtuous. It formed this "undifferentiated mass of those who have no positive qualification - no wealth, no virtue-but who are nonetheless acknowledged to enjoy the same freedom as those who do ([2], p. 8).” Having no positive qualification is what led Aristotle to describe the people as having "no part in anything” ([1], pp. 25-28; [2], pp. 6-9).

In short, the notion of "part without part" refers to a part of society that is designated as such, but which really does not have any (substantive) share in the common power. Though formally recognized, in practice it is excluded and dominated by the parts that do have a share of that power. This dominion and exclusion constitute the double injustice that is constitutive of the political order. For the wealthy parts, the claim of the people to partake in the common matters is an injustice to the order of things, to the way the parts are distributed in society. As for the people, the part without part, the injustice lies in their exclusion. So rises that disagreement between parties that lies at the basis of all politics ([1], p. 44).

This diametrical opposition reflects the opposition between politics and police. Rancière qualifies the first as being the equality test of "anyone at all with anyone else" ([2], p. 15). This means that the part without part demands to be treated equally, stop being excluded. As it is the test of anyone at all with anyone else, this can also mean that a third party may ask this test to be done on behalf of the part without part. Two consequences of this matter to us: (1) for anyone to demand this equality test, means that the part without part is being recognized as such; (2) hence, as anyone may ask for this test, and therefore has an interest in it, the part without part has a universal reach in terms of justice and emancipation. This is why Rancière can say that "[p]olitics exists when the natural order of domination is interrupted by the institution of a part of those who have no part” ([2], p. 11). So politics is a question of momentum — so that we may speak of a political moment or political momentum.

The opposite of politics is police. Rancière uses the foucaultian notion of police, which goes back to the use of term of the seventeenth and eighteenth centuries, which indicates a mode of government of the people covering the wellbeing of the citizens. By police, Rancière intends thus:

an order of bodies that defines the allocation of ways of doing, ways of being, and ways of saying, and sees that those bodies are assigned by name to a particular place and task; it is an order of the visible and the 
sayable that sees that a particular activity is visible and another is not, that this speech is understood as discourse and another as noise ([2], p. 29).

By today's standards, this notion of policing is equivalent to the management or governance of society. It has a very technical connotation, as can be deduced from the various tasks of assigning places and tasks and the arbitration between legitimate discourse and illegitimate noise.

Politics and police are opposites because whereas the latter governs an order of things-implying that everything and everyone has the place and share they deserve in the community-the former disrupts this order demanding an equality test because of a fundamental injustice ([1], pp. 52-53). Hence, the author concludes that:

The party of the poor embodies nothing other than politics itself as the setting-up of a part of those who have no part. Symmetrically, the party of the rich embodies nothing other than the antipolitical. From Athens in the fifth century B.C. up until our own governments, the party of the rich has only ever said one thing, which is most precisely the negation of politics: there is no part of those who have no part ([2], p. 14).

\subsection{The Exclusion without Justification of Normal Migrants}

In On the Right of Exclusion, Bas Schotel introduces the notion of "normal migrants", “i.e., migrants who do not have a legal right to admission” ([3], pp. 1, 11). Whereas asylum seekers, family members of permanent immigrants have a legal right to be admitted, normal migrants can only be admitted at the discretion of the receiving state. Furthermore, "migrant" is a socio-economic term that grasps the reality and quantity of movement and policies better than its legal equivalent "alien". In fact, normal migrants constitute the largest group of migrants. Lastly, as a socio-economic term, the word "migrant" fits easily within policy discourses where the shift is easily made from "migrant" to "migration flows" to "management of flows". Hence, whereas alien somehow indicates a legal subject, with the term migrant a slip occurs toward "an object of policy” ([3], pp. 11-13).

Schotel describes European (and other Western) admission policies as practices of the exclusion of normal migrants without justification. Based on figures of Eurostat and of the Council of the European Union (EU), he estimates that on a yearly basis Member States of the EU exclude approximately two million normal migrants ([3], pp. 8-27). Thus, exclusion is the normal practice when it comes down to admission policies. This is proven also by both the legal doctrine and case law of the past 150 years, which "converge in stating that the exclusion and expulsion of aliens are matters of State sovereignty and discretionary in nature ([4], p. 328)."

Schotel argues that for laws and administrative acts and decisions to be legitimate, they should be justified properly. In cases of non-admission, proper justification would mean going through the specific merits of each case to show that there are imperative reasons for excluding the individual in question. The authorities must have shown that the exclusion is necessary to obtain the objectives of immigration policy and that exclusion was the only and the least burdensome measure available. In other words, the principle of proportionality should apply to acts of exclusion. The abstract and general justifications referring to provisions of the law that accompany refusals do not count as proper as they do not go beyond this mere formality. Nonetheless, as mentioned above, the standard case law of various national, supranational and international courts has supported the absence of proper 
justification by systematically referring to the inherent sovereign power of states to decide who they admit onto their territory ${ }^{1}$ ([3], pp. 27-36).

For there to be proper justification, the legitimate interest of the normal migrant must be taken into consideration and balanced against the interest of the state. In fact, for laws to have authority they must be able to "have the capacity to have legitimate authority", which means that "the law must reflect the reasons that are directly applicable to the relevant individuals from whom it requires obedience”, or, to put it simply, that "the law can show that it took into account the reasons that concern the relevant individuals” ([3], p. 120). Yet, since admission policies are characterized by state discretion, they lack this capacity to have legitimate authority. Moreover, a crucial aspect of legitimate authority depends on whether, in general, its norm-subjects benefit more from following that law than from disobeying it, as it would mean that their legitimate interest is taken into account. Once more, precisely because of the discretionary nature of admission policies and of the exclusionary paradigm, normal migrants rather disobey, which means that the laws lack the capacity to have authority ([3], pp. 120, 133-35).

\subsection{The Normal Migrants as the Part without Part}

The reason for this somewhat abstract political philosophical introduction is that, in the light of Schotel's analysis, it captures well the current framework of Western immigration policies. The normal migrants represent the part without part, whereas the practice of exclusion, backed up by the laws, policies and case law are clear testimonials of the denial of this part without part. So each claim normal migrants - or defense associations on their behalf-make to their human rights in order to legalize and justify their presence on the territory, can be seen as a demand for an equality test of anyone with anyone else.

In fact, if we take into consideration that under international law the right to liberty is guaranteed ([3], pp. 32-33; [5], p. 575), how do we explain that this human right does not apply to normal migrants except by asserting that they have no part in it? In this respect, Schotel's observation that "[t]he law does not organize the rights of the alien but only the rights over the alien" is wholly accurate and corresponds to the field of policing described by Rancière. Against that, recognising the legitimate interest in migration of normal migrants, even if only indirectly, corresponds to the political moment where it is recognized that they constitute a part without part.

The analogy goes further. Like the freedom of the demos, human rights are the empty and negative quality of all displaced persons. They are intended to protect all humans and are therefore common to all of them. Nonetheless, in terms of Hannah Arendt's paradox, as soon as human beings were no longer able to count on the protection of their own government, their human rights were no longer guaranteed either ([6], pp. 291-92). Thus, human rights are this empty property, which migrants can invoke to claim they are part of the human family, but which will not better their situation, although they have no choice but to do so in order to become visible and disrupt the order of domination. In fact, though Arendt's human rights paradox is still certainly valid, it needs nuancing as the standing

1 See for instance U.S. Supreme Court, Nishimura Ekiu v. United States, 142 U.S. 651 (1892); Privy Council, 6 and 27 July, 1906, Attorney-General for the dominion of Canada v. Everett E. Cain; Attorney-General for the dominion of Canada v. Gilhula, (1906) A.C. 542. In BILC, op.cit., (181) 183; European Court of Human Rights (26 June 1996$)$, Amuur v. France, §41; (12 October 2006), Mubilanzila Mayeka and Kaniki Mitunga v. Belgium, §96. 
and enforcement of human rights have evolved since. As Louis Henkin pointed out, with the adoption of the UN Charter not only would human rights increasingly gain in importance, but slowly they would delimit state sovereignty so that "resistance to 'enforcement' [has become] the last bastion of 'sovereignty'” ([7], p. 33).

As such, just like the freedom of the demos was this negative quality limiting the rights of the wealthy and the noble over it, from the second half of the twentieth century onward-especially in Europe with the adoption and implementation of the European Convention on Human Rights and Fundamental Freedoms (ECHR) - human rights started to limit state sovereignty also in immigration cases. This limitation did not come through the recognition of a human right to immigration. Rather it came along thanks to the European Court of Human Rights' (ECtHR) theory of the convention as a "living instrument". In fact, the ECtHR developed a kind of corpus iuris of immigration, reasoning on the basis of "the case law it had developed in different but similar domains such as extradition, detention or the general obligation on Contracting Parties to secure the rights and freedoms of the ECHR” ([4], pp. 350-51). What is often at stake in immigration cases before the ECtHR are the prohibition of torture and degrading treatment (article 3 ECHR), the right to liberty (article 5 ECHR), the right to family life (article 8 ECHR) or any of these rights in combination with the right to effective remedies (article 13 ECHR). None of these establish a right to immigration, which is the substantial claim of each excluded normal migrant, but they set a normative framework within which immigration policies are to be carried out. In this way, the sovereign right of states is recognized, but it is limited at the same time by this empty and negative quality we call human rights. This limitation indirectly recognizes the legitimate interest of the normal migrants and thus represents a political potential. So in recognizing their right under the ECHR, their legitimate interest is so too, though only indirectly. Consequently, the normal practice (police) of detention is disrupted by the affirmation of liberty. This is a political stake.

The ECtHR has played a fundamental role in the development of a corpus iuris of migrant's human rights and deserves some attention here. Thus we now look briefly at the impact of the human rights case law of the ECtHR on the immigration policies of Member States and of the EU, as it sets the framework within which the Court of Justice of the EU (CJEU) interprets the Return Directive (RD) and in extenso should interpret other EU migration policies.

\section{Delimiting Sovereignty-The Human Rights Spill-Over}

As the ECHR was not intended as an instrument of immigration policies and laws, but nonetheless impacted on them, the limiting of the margin of appreciation of states in implementing these laws and policies can be considered the result of a spill-over effect of human right norms ([4], p. 321). In fact, the safeguards that were built throughout the case law can be considered to have impacted at the procedural level on the implementation of migration and asylum policies of the Member States. Thus, first the ECtHR established that the Soering doctrine was applicable to expulsion cases ([8], §§69-70). The Court then added that this principle prevailed irrespective of the conduct of the individual in question and of issues of national security as the prohibition under article 3 "is absolute in expulsion cases” ([9], §§79-80). Later it found that Contracting Parties had, within the scope of article 3, a duty to rigorously scrutinize the risks of ill-treatment following expulsions and were held liable under 
article 13 (effective remedies) if they failed to do so ([10], §§39-42, 44-50). Furthermore, on numerous occasions, the ECtHR found that the conditions of detention raised issues under article 3 , namely when the state of the detention center was dilapidated, unhygienic or when the detainees had no access to the open air (possibility to walk), no leisure, or recreational activities. ([11], §§216-22; [12], $\S \S 49-65 ;$ [13], §§43-54).

To summaries the above, although the ECtHR looks into (possible) violations of a substantive nature of the ECHR, it has developed guidelines for the Contracting Parties to apply if they want to be sure they do not breach the Convention when detaining and expelling aliens (normal migrants and asylum seekers alike). Hence, these substantive rights closely resemble the procedural safeguards states must comply with. This was strengthened, reaching EU-policy, with the judgment in M.S.S. v. Belgium \& Greece [11]. Not only did the Court impose obligations on the Contracting Parties, but in doing so it indirectly impacted on substantive Union law, in casu the Dublin regulation. Having considered that membership of the EU does not suffice to guarantee asylum seekers the safeguards under article 3 ECHR, the ECtHR imposed the duty to make use of article 3(2) of the Dublin II regulation (sovereignty clause). Thus, it put a halt to automatic transfers of asylum seekers to the Member State responsible for the examination of the asylum claim based on mutual trust, which is one of the cornerstones of European integration [14-16]. The Court reasoned that since Belgium could have acted according to the sovereignty clause to examine whether M.S.S. would be subjected to degrading treatment, the presumption of equivalent protection did not apply ([11], §§339-40).

In its reception of M.S.S. the CJEU managed to avoid the potential conflict between Union law and ECHR by turning the sovereignty clause into a duty of the Member States whenever

there are substantial grounds for believing that there are systemic flaws in the asylum and reception conditions for asylum applicants in the Member State responsible, resulting in inhuman or degrading treatment, within the meaning of Article 4 of the Charter [of Fundamental Rights] (...) ([17], §86).

In such cases, the transfer would be incompatible with Article 4 of the Charter of Fundamental Rights (CFR). The CJEU considered the substantial grounds taking into account the evidence gathered before the ECtHR in the M.S.S. case. Hence, the CJEU concludes that the Dublin regulation prohibits Member States, "where they cannot be unaware" of systemic deficiencies in the reception conditions of the responsible Member State, from sending the applicant to that Member State ([17], §94). In such cases, the sending Member State must continue to examine the criteria of the regulation to see whether another Member State might be responsible. If there is no other responsible Member State, the sending Member State will have to use the sovereignty clause and itself examine the asylum claim ([17], §§107-08).

The interesting shift operated in this preliminary ruling, is that Article 3(2) of the Dublin regulation, the so-called the sovereignty clause, becomes a duty under Union law [15]. Thus, in the EU-order too, human rights imperatives impose new duties on Member States since these duties amount in effect to procedural safeguards, which limit their sovereignty. As it will have to interpret specific matters of EU-law in the field of migration and asylum, the further development of the right of normal migrants lies within the hands of the CJEU. In the following section, we will illustrate this through the case law of the RD. 


\section{Limiting State Discretion Even More-The Unattended Effect of the Return Directive ${ }^{2}$}

After the spill-over of human right norms into immigration and asylum matters of sovereign states, the general principles of law of the EU further limited the discretion of states in those matters. Immigration and asylum having become competencies of the Union, Member States must act according to both principles of proportionality when executing their policies in areas in which the EU has laid down rules: the first, in the measures taken to attain the objectives of the Union (article 5 of the Treaty of the European Union (TEU)) in the light of the principle of sincere cooperation (articles 4(3) and 13(2) TEU); and the second, in the measures taken in relation to individuals, guaranteeing their fundamental rights (article $6 \mathrm{TEU}$ and article $52 \mathrm{CFR}$ ). With the adoption of Directive 115/2008/EC, also known as the Return Directive (RD) or even "Shame Directive" by human rights activists, both principles of proportionality were inscribed into the procedures of detention and expulsion of normal migrants where it had previously not applied. Hence, recital 20 of RD inscribes the first principle of proportionality stating that the issues of removal, return, entry-bans, and so on, of irregular migrants can be addressed better at the Union level. Thus, while legislating the Union should not adopt measures that go beyond the necessary ones to achieve the set out objectives. This first proportionality is measured against the second one relating to the fundamental rights (recital 13 and 16). Coercive measures and detention should only be used as a last resort and in full respect of the fundamental rights. Hence, the provisions of the RD include, and are directly limited by, the fundamental rights. For example, article 15 explicitly limits the possibilities of detention and article 16 sets out the conditions in which this must happen.

These provisions, which include fundamental rights safeguards, have thus become objectives of the EU. In other words, not just the effective removal procedures are objectives of the RD, but also the respect of the procedural safeguards. This is evident in the case law of the CJEU that developed soon after the entry into force of the Directive, and even more so once the deadline for transposition had expired. The CJEU never recognizes the fundamental rights of normal migrants directly, but only indirectly as objectives of the Union. When Member States exceed in their zeal to expel, the CJEU will consider this as a breach of the proportionality principle in the light of the principle of sincere cooperation, because the excess goes against the objectives of the EU. It does not mention the heavy burden it puts on the individual.

In the following paragraphs, we review this case law and argue that this new instrument of EU policy has opened some political space for normal migrants. I argue that since the recognition of human or fundamental rights indirectly recognizes the legitimate interest of normal migrants; and that the principles of proportionality and sincere cooperation indirectly recognize these rights as their are part of Union law, by transitivity the case law of the CJEU recognizes the legitimate interest of normal migrants in immigration. In doing so, a political momentum is created on the basis of legal reasoning

2 We review all the Return Directive cases up to 30 September 2013 with the exception of the Mehmet Arslan case (C-534/11) as it concerns an asylum seeker and where the referring court asked whether the said Directive is applicable, which it is not; and the case of M.G. and N.R. (C-383/11) as it did not explain further duties or set procedures to be followed by the Member States, contrary to the other cases, but merely sheds light on a point of law for the referring court. Thus out of the eight cases, only four six of importance here. Furthermore, two of these cases are only mentioned at the end of the paragraph of the Achughbabian case as they are very similar. 
and challenges to be taken to court (as much as possible). This is the subject of the final section of the paper where we focus on two domestic cases in Italy and France respectively. ${ }^{3}$

\subsection{Setting the Procedural Safeguards: The Kadzoev Case [18]}

Kadzoev, a Chechen national, was arrested at the Bulgarian-Turkish border on 21 October 2006 by the Bulgarians. He had no identity documents. The following day a measure of deportation was imposed on him, but it could not be carried out immediately as he still needed to be identified, travel documents found, tickets to Chechnya to be bought, and so on. For the preparation of his removal, he was placed in a detention center on 3 November 2006. Only on 14 December did Kadzoev declare his real name. His identity was considered proven by the Bulgarian courts and in the period between January 2007 and April 2008, the Bulgarian and Russian authorities consulted each other concerning Kadzoev. Whereas the former validated his identity, the latter would not recognize the documents presented to them by their Bulgarian counterparts. Between May 2007 and March 2008 Kadzoev applied three times for asylum. His first and last applications were rejected and he withdrew the second one. In the meanwhile, he was still being detained in view of expulsion. His lawyer petitioned twice for a less severe measure than detention to be applied, namely the obligation for Kadzoev to periodically sign a register kept by the police. At the end of October 2008, this last application was also rejected. On 12 March 2009, the Supreme Administrative Court (SAC) judged that since it was not possible to ascertain the nationality of Kadzoev, he was to be considered stateless. Furthermore, several NGOs and the UNCHR found it credible that Kadzoev was a victim of torture. Several attempts were made, in collaboration with Kadzoev himself and the NGOs to send him to a safe third country, but no agreement was reached, nor any travel documents obtained.

In the meantime, Kadzoev was still being detained in view of his removal. In fact, before the transposition of the RD, Bulgarian law did not provide a maximum period for detention. In 2009, the Directorate for Migration at the Ministry of Interior asked the SAC to rule on the continued detention of Kadzoev. By then the said directive had been transposed into Bulgarian law. The SAC decided to stay the proceedings and ask the CJEU for a preliminary ruling.

The first two questions of the referring court are quite similar. In question 1(a) the referring court asks whether the detention completed before the rules of the Directive became applicable is to be included when calculating the maximum duration of detention. The CJEU applies its typical teleological interpretation to say it does, because otherwise people in similar situations could be detained longer than the maximum period mentioned in the Directive and this would not be consistent with its objectives ([18], §§36-39).

In questions 1(b) and 2 is asked, respectively, whether the period during which an asylum claim is being examined and the one during which the execution of the deportation decree is suspended due to judicial review, should be included in the calculation of the maximum period. The CJEU recalls that the detention of asylum seekers is governed by Directive 2003/9/EC and that as a rule they should not be detained. So if Kadzoev were to be detained as an asylum seeker, this should have happened on the

3 For the analysis of the case law, we use the terminology of the CJEU and speak of third-country nationals (TCN) instead of normal migrants. However, they must be considered as equivalent, as none of the cases involves migrants without a legal right to admission [3]. 
basis of a new decision and in accordance with that Directive. If this were not the case, meaning that Kadzoev was being kept in detention on the basis of the same decision, then the period of examination of the asylum application must be included in the calculation ([18], §§41-48).

In its answer to question 2, the CJEU applies its teleological interpretation again. It states that in the $\mathrm{RD}$ a suspension of removal for judicial review is not mentioned as a ground for extending the period of detention. Hence, this period must be taken into account. If this were not so, the duration of the detention could vary from one Member State to another, which would run counter to the objective of said Directive ([18], §§51-54).

Question 3, which is divided into three parts, seeks clarification of the concept of "reasonable prospect of removal”. In questions 3(a) and 3(b) the referring court asks whether when no agreement is reached with the state of which the detained is a national nor with another third country that should be considered as there no longer being a reasonable prospect of removal, even though the authorities keep looking for a country that will receive the migrant. The CJEU's answer is vague. Though it states that detention ceases to be justified and that the individual must be released when there is no reasonable prospect of removal due to legal or other considerations, it does not seem to answer the referring court's question. The CJEU adds that detention may be maintained if arrangements are in progress and that it is necessary for successful removal. Furthermore, this must happen within the time limits set in the Directive ([18], §§63-66) Thus, the somewhat tautological answer of the CJEU

that only a real prospect that removal can be carried out successfully, having regard to the periods laid down in Article 15(5) and (6), corresponds to a reasonable prospect of removal, and that that reasonable prospect does not exist where it appears unlikely that the person concerned will be admitted to a third country, having regard to those periods ([18], §67).

The CJEU seems to imply that it does not suffice that a Member State is looking for a country to which to remove the individual. For it to be considered a reasonable or real prospect, arrangements must be in progress between that Member State and that other country. What is more is that where the maximum period of detention has already expired, the individual has to be released immediately. In such a case, the concept of reasonable prospect does not apply anymore-which is also the answer to question 3 (c) ([18], §§60-62).

With its last question the referring court wants to know whether detention can be further maintained even though the maximum period has expired on the grounds that the person concerned is not in possession of valid documents, has no means of subsistence and his conduct is aggressive. The CJEU's answer is clear and effective: in no case does the Directive allow the maximum period to be exceeded ([18], §69).

It is interesting to note how in both questions 2 and 4 the referring court added as elements to be considered that Kadzoev had no valid identity documents, no means of subsistence and that his conduct was aggressive. These are elements usually used to invoke public order or national security. However, the CJEU did not pay the slightest attention to these elements, thereby implying that they are not at all relevant for detention and removal under the Directive. In fact, in its answer to question 4, the Court added, without mentioning the conduct or status of Kadzoev, that the Directive may not be used for detaining someone on grounds of public order or safety ([18], §70).

This judgment is interesting for us because it sets procedural safeguards Member States must comply with to achieve the objectives of the RD. In fact, whenever the safeguards are not complied 
with, "the detention ceases to be justified and the person concerned must be released immediately". If this were not so, the Union law would be breached. The principle of proportionality implicit in this judgment seems to be the one relating to the achievement of Union goals, rather than relating to fundamental rights ([18], §§37, 54). Hence, only indirectly, the CJEU is protecting the fundamental right to liberty, which, in expulsion cases, seems to prevail over public order and safety.

\subsection{Limiting Criminal Detention: The El Dridi Case [19]}

El Dridi, a TCN who entered Italy illegally and who did not hold a residence permit, was issued a deportation decree in May 2004. A new deportation decree was issued on May 2010, at the moment of his release after having served a sentence for drug crimes in the meantime. At the end of September 2010, a check revealed that El Dridi had not complied with that order and so he was sentenced to a year's imprisonment. He subsequently appealed that decision. The Appeal Court of Trento stayed the proceedings as it was not sure whether a criminal penalty may be imposed during an administrative return procedure, it being potentially contrary to the attainment of the scope of the Directive and to the principle of sincere cooperation. Furthermore, it doubted whether such a penalty was proportionate. In these circumstances, the Appeal Court wanted to know whether the Directive precluded the possibility of a criminal penalty, i.e., imprisonment, even before the administrative procedure had been completed; and whether it precluded the possibility of an imprisonment of up to four years for a simple failure to cooperate with a deportation procedure ([19], §§18-25; [20], p. 478).

The CJEU starts by addressing the issue of the criminalization of illegal stay. It recalls that under article 2(2)(b) of the Directive, Member States may decide not to apply it to TCNs subjected to a removal as a criminal sanction, but adds an important nuance, namely that the criminal legislation and rules of criminal procedure should not jeopardize the objectives pursued by Union law as that would deprive the Directive of its effectiveness. With all this in mind, the CJEU concludes that Members States may not imprison an illegally staying TCN on the sole ground that he is staying illegally and that he has failed to leave the territory after an order had been issued. The Member State must then pursue its efforts to enforce the return decision. A criminal penalty, in casu imprisonment, would frustrate the removal procedure and as such jeopardize the attainment of the objectives of the Directive. The national courts are thus called upon not to apply such provisions and to "take into account the principle of the retroactive application of more lenient penalties". However, where coercive measures have failed, Member States may adopt criminal law provisions to deter and dissuade TCN not to leave the territory ([19], §§49-61; [20], pp. 481-82).

The impact of this judgment on the national laws of Member States that criminalized illegal stay is clear: it is illegal if it frustrates the Directive. It is also very important as it establishes the successive stages and various possibilities of the removal procedures, which should go from the least coercivegranting the individual a period for voluntary departure - to the most coercive-pre-removal detention. Where Member States have not followed this procedure, TCNs who are being detained must be released, as that detention is unlawful. Hence, in the name of the effet utile of the Directive, the fundamental rights of normal migrants have been safeguarded, albeit indirectly. This is strengthened by the explicit reference the CJEU makes to article 4(3) TEU, i.e., to the principle of sincere cooperation ([19], §§56-59). In fact it did not construct its reasoning on the grounds of the 
fundamental rights, but its reasoning produces this effect ([20], pp. 484-86) since the respect of these rights is an objective of the $\mathrm{RD}$.

However, the judgment left open a possibility to criminalize illegal stay and migration, once coercive measures have failed to ensure removal, as a way of dissuading TCNs to do so. Moreover, since the CJEU did not specify when the return procedure is considered to have started, Member States have tried to use the possibility of criminalizing irregular immigration and stay to circumvent the Directive, as can be seen in the following case.

\subsection{Forbidding the Circumvention of the Directive: The Achughbabian Case [21]}

During an identity check on the public highway on 24 June 2011 Achughbabian, an Armenian national, was suspected of staying illegally in France. On the basis thereof, he was placed in police custody. After an examination of his situation it was revealed that he had applied for a residence permit in April 2008, but that it had been rejected in November of that same year and confirmed in January 2009 at which point he had been ordered to leave the territory within one month. Hence, on 25 June 2011 a deportation order and an administrative detention order were adopted by the French authorities. On 27 June, this detention was reviewed and prolonged beyond the 48 hours provided for by law by the competent court. Achughbabian appealed this decision to the Court of Appeal in Paris, which stayed the proceedings asking the CJEU whether the Directive precluded "national legislation which provides for the imposition of a sentence of imprisonment on a third-country national on the sole ground of his illegal entry or residence in national territory?” The background of this argument is that in France, police custody may only be applied for offences punishable by imprisonment, which is the case for illegal entry and stay in France. However, since the CJEU ruled that such imprisonment jeopardized the attainment of the objectives of the $\mathrm{RD}$, the question remained whether this was still applicable before the start of a return procedure [22].

The CJEU opens its analysis by reiterating the possibility of Member States to adopt criminal law provisions in matters of illegal immigration, though they may not conflict with Union law. Furthermore, the Directive allows Member States to resort to detention in view of determining the status of the individual. In fact, the scope of the Directive would be undermined if Member States could not resort to such measures. However, this deprivation of liberty may only last for a "brief but reasonable time to identify the person under constraint and to research the information enabling it to be determined whether that person is an illegally-staying third-country national." Though the identification process may prove to be difficult, especially in cases where the individual does not cooperate or invokes the status of asylum seeker, the authorities must act with diligence "and take a position without delay on the legality or otherwise of the stay of the person concerned.” In fact, once "it has been established that the stay is illegal, the said authorities must (...) adopt a return decision ([21], §§28-31).”

The CJEU then turns toward the analysis of the French legal provision for imprisonment of illegally staying TCNs as it may conflict with Union obligations. It reiterates its analysis of the El Dridi case stating that such imprisonment hampers the return procedure, depriving it of its effectiveness. In the present case, the CJEU notices that the first deportation order (of 2009) was no longer operative and therefore the French authorities adopted a new one. At any rate the provisions of the Directive (article 8) 
compelling Member States to assure that removal takes place "in an effective and proportionate manner”, whether using coercive measures or not, are applicable. In that respect a detention measure of the person concerned is allowed for the purposes of preparing and permitting the removal and it may not last more than 6 months to which an additional year can be added "only where non-implementation of the return decision during the said 6 months is due to a lack of cooperation from the person concerned or delays in obtaining the necessary documentation from third countries." Furthermore, the CJEU argues that an imprisonment during the return procedure does not contribute to the removal and thus cannot be considered to be a measure or a coercive measure within the meaning of the Directive ([21], §§33-37).

For the CJEU it is therefore obvious that such an imprisonment measure is precluded by the Directive as it would deprive it of its effectiveness. Such an imprisonment is only allowed where the person concerned is subject to criminal law expulsion. The latter, which does not fall under the scope of the Directive, is only applicable where the person concerned committed one or more offences other than that of illegal entry or stay, which was not the case of Achughbabian. Hence, even though according to the French authorities, in practice imprisonment usually does not follow in cases where no other offence was committed, the CJEU finds that this mere possibility is still theoretically available and that this should not be possible as it may "compromise the application of the common standards and procedures” introduced by the Directive ([21], §§38-44).

In the final part of its judgment the CJEU rebuts the claims according to which, although a prison sentence may not be imposed during a removal procedure, it may be imposed before the removal is carried out. This would be contrary to the obligation to immediately start a return procedure as soon as possible once it has become clear that the person concerned is staying illegally. However, referring to El Dridi, the CJEU recalls that a prison sentence may be provided for in cases where "coercive measures have not made it possible for the removal of an illegally staying third-country national to be effected” provided that there is no justified ground for non-return ([21], §§44-48).

As Raffaelli [20] points out, in the El Dridi case the CJEU had left open the possibility of criminalizing illegal stay after coercive measures of removal had failed. In such cases, the matter would no longer fall within the scope of the Directive. This gave rise to practices of Member States trying to circumvent the application of the Directive. Hence, in France, such as was the case of Achughbabian, but also in Italy and Germany for example, illegal entry as such was punished with imprisonment and a fine ([20], pp. 486-87). As such, the TCN in question fell within the scope of criminal law and it was argued that he would not fall under the scope of the Directive.

The importance of the Achughbabian case is that though Member States may, under national legislation, detain an irregularly staying TCN in order to identify him and his situation, this detention must be brief and may not lead to imprisonment. In fact, as soon as it appears that the person concerned is staying illegally in the country, the removal procedure begins. This seems to be irrespective of whether the nationality of the person is ascertained. From the judgment it seems to suffice that the person appears to be staying illegally, which can be deduced by lack of cooperation, silence, lack of identity documents, and so. Though the case may not be a victory in the eyes of human rights activists, it remains important as it further limits the margin of appreciation of Member States in how they criminalize migration. Here too, what matters to the CJEU is the correct application of the provisions of the RD so as not jeopardize the achievement of its objectives, explicitly referring to the 
principle of sincere cooperation ([21], §§33, 43). The CJEU does not forbid criminalization, but it certainly limited the scope and possibilities thereof.

After the Achughbabian case, two Italian courts referred to the CJEU asking whether national legislation criminalizing illegal stay as such, which, according to the wording of one of the referring courts, was intended "to circumvent or, in any event, limit the scope of the directive", was precluded by the principle of sincere cooperation ([23], §26). In both cases, the courts asked whether in the light of that principle the Directive allowed for the criminal fine imposed upon illegal stayers to be replaced with an expulsion order. The CJEU stated that this was allowed, but emphasized that this fell under the scope of the Directive even though it is regarded as a criminal sanction under domestic law [23,24].

\subsection{Limiting Discretion under Article 2(2)(b) RD: Filev and Osmani [25]}

In the case of Filev and Osmani, a referring German court asked whether the Directive precluded criminal sanctions for the breach of re-entry bans that had been handed out before the coming into force of the Directive and which provided for a ban of more than five years. Filev's asylum application was rejected in 1992 after which he had to leave Germany and received a re-entry ban that was not limited in time. When he came back to Germany in April 2012, he was checked at the border and subsequently subjected to criminal proceedings for non-compliance with that re-entry ban. He was held in police custody and received a fine. Osmani received an expulsion order in 1999 due to a conviction in a drug crime. In 2003 he was convicted again, served part of his sentence and was subsequently removed from Germany with a re-entry ban not limited in time. His early release was made conditional upon him serving the remaining 474 days in case of re-entry. When he came back in April 2012, he was checked at the border and criminal proceedings were initiated.

As the Directive only provides for entry bans for a period of maximum five years and the German re-entry bans had been handed out more than five years before the entry into force of the Directive, the referring court asked for a preliminary ruling. The court wanted to know whether the Directive precludes Member States "from making breaches of administrative law expulsion or removal orders subject to criminal law sanctions, where the expulsion or removal order was made more than 5 years prior to re-entry" and more than five years before the entry into force of the Directive in the domestic legal order (questions 1 and 2). It also wanted to know whether national legislation, which does not provide for a time-limit on re-entry bans unless the person concerned explicitly asks for one, is compatible with the Directive (question 3). Lastly, regarding only Osmani, the court wanted to know whether new criminal proceedings may be started on the same grounds as an expulsion order that predates more than five years the entry into force of the Directive as also its transposition into the domestic order (question 4).

With regard to the third question, the CJEU says that the wording of the Directive is clear and imposes a duty upon Member States to determine a period during which the entry ban is valid and that may not exceed five years. Furthermore, had the EU "legislature intended to provide Member States with a discretionary power in relation to determining a limit to the length of an entry ban, it would have done so expressly” as it did in other articles. The objective of the Directive is that entry-bans do not exceed five years except for reasons public order or national security ([25], §§25-34). 
The CJEU then moves on to analyze the first and second questions together. It examines whether the entry bans comply with the Directive. In that respect, as the Directive does not provide for any transitional arrangements in relation to entry ban decisions, its settled case law applies, meaning that the new rules are immediately applicable except in the event of a derogation. Thus, to see if the old entry bans are still applicable one must examine for how long they have been applied before the entry into force of the Directive, lest the entry ban were to exceed five years. In the present cases, the continued effect of the old entry bans would be contrary to the provisions of the Directive and are therefore precluded by it, except in cases where they were issued against a person who posed a threat to national security or public order. Hence, not only may such entry bans no longer be applicable, neither may criminal proceedings follow from a breach of these entry bans, except in the cases of threat to national security and public order ([25], §§35-45).

With its fourth question, the referring court basically wanted to know whether new criminal proceedings may be started on the same grounds of an expulsion order that predated by more than five years the entry into force of the Directive as also its transposition into the domestic order. Moreover, it asked whether it may fall under article 2(2)(b) of the Directive, which would remove them from the scope of the Directive.

In the view of the CJEU, a Member State may apply the exception under article 2(2)(b) so as to exclude criminal cases, such as Osmani's, from the scope of the Directive. However, if a Member State has not made use of this discretion after expiry of the said time period for implementation, older decisions will automatically fall under the scope of said Directive and the protection it confers upon the subjects of such decisions. Hence, after the expiry date for implementation Osmani was covered by the Directive and the five years rule applied. As Germany only made use of its discretion under article 2(2)(b) after this expiry date, applying it to Osmani would suddenly worsen his situation. Consequently, no criminal proceedings may be started on the basis of that old removal or expulsion order ([25], §§50-56). Once more, the CJEU affirmed the direct effect of the Directive and the seriousness of its provisions. As these provisions are precise and confer rights upon their norm-subjects, these rights are considered objectives that must be achieved and respected ([25], §§32-37). Though its principle aim is not to protect the fundamental rights of TCNs, the scope of harmonizing practices and procedures has led to preclude old entry bans that were much more severe and to preclude further criminalization for breach of such bans, as they are no longer lawful. The consequence of this judgment can be great, as in the past many normal migrants have been expelled and received entry bans such as the ones in the case at hand. It will mean that they can try to enter the EU again without having to face criminal proceedings. Once more, the fundamental rights of TCN have been recognized indirectly.

The CJEU does however allow exceptions in cases of serious threats. In the case at hand it did not, however, examine this question, nor did it refer to any case law on the matter. Yet, it is reasonable to suppose that it would be loyal to its settled case law and that such a threat would be gauged case by case as a present and sufficiently serious threat and not simply based on past convictions ([26],

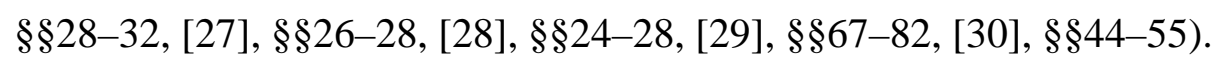




\subsection{Intermediate Conclusions}

The purpose of this section was to show how after the ECtHR indirectly recognized the legitimate interest of normal migrants by taking into consideration their human rights, the CJEU's interpretation of the RD on the basis of the principle of proportionality and sincere cooperation further limited the sovereignty of states in migration matters. This has been made possible in two distinctive moments. First, when the principle of proportionality relating to the fundamental rights of individuals was inscribed in the RD. As such, these rights became objectives of the EU. Secondly, when the CJEU found Member States to be in breach of the principles of proportionality and of sincere cooperation when they took disproportionate measures as they impeded the achievement of the objectives of the $\mathrm{RD}$, which include fundamental rights safeguards. As mentioned above, indirectly the CJEU recognizes these fundamental rights, which in turn indirectly recognize the legitimate interest of TCN. So paradoxically, the $\mathrm{RD}$ recognizes the fundamental rights of normal migrants and thus indirectly their legitimate interest, since it limits the possibilities of the Member States.

The most important limitation is that regarding the detention of migrants. In many, if not all, Member States pre-removal detention was applied (almost) automatically even though national legislation provided less severe alternatives. Furthermore, the CJEU explicitly stated that no derogations on the basis of national security, public order, and so on, may be grounded in the $\mathrm{RD}$, as was often the case in Member States to prolong detention or refuse entry. As to the prolongation of detention, the CJEU clearly stated that after six months, the additional twelve months provided for by law may only be invoked under specific conditions, namely that removal is still possible and that it has failed due to lack of cooperation of the person concerned. Last but not least, though it has asserted the Member States' right to criminalize irregular immigration and stay as a deterrent, the CJEU clearly affirmed the supremacy of EU law over national criminal law. In other words, these criminal provisions may not hamper the achievement of the objectives of the RD. In particular, this is the case for imprisonments during or before a return procedure. As to the imprisonment after such a procedure failed, this will only be possible if the person concerned is still on the territory without a justified ground for non-return. Though the CJEU did not list such possibilities, it is reasonable to consider that whenever removal failed for reasons independent of the TCN (because s/he is stateless, or because the Member State was not able to find a country willing to accept him/her, or is not able to expel without violating fundamental rights, etc.) criminal sanctions will not be applicable as this would be disproportionate. Therefore, the possibilities of legalistic criminalization, which is a competence of the Member States, have been vastly reduced.

The political potential of the $\mathrm{RD}$ has been realized as it disrupted the normality of detention and other measures (disproportionate entry bans, criminalization). So though normal migrants are mostly objects of policy (and police), thanks to the RD and its interpretation by the CJEU, they have gained extra ground for legal standing, thus slowly becoming ever more subjects of law.

\section{The Impact in Italian and French Case Law: Two Cases of Political Momentum}

In this section we discuss an Italian and a French case where the political potential of the Return Directive, i.e., the (indirect) recognition of the legitimate interest of normal migrants is not only 
particularly evident, but might actually change national policies and practices regarding the detention of migrants.

\subsection{Self-Defense Against Detention-The Italian Judgment [31]}

Aarrassi, Ababsa and Dhifalli were three undocumented migrants held in the detention center of Crotone in the South of Italy. On 9 October 2012, they started a protest against their detention and against a routine search by the police during which the people and rooms were checked for items that might be used for escape. The protest turned violent when the three occupied the roof top of the center from where they started throwing window frames, bricks, furniture, taps, and so on, in the direction of the police and the staff of the center so as to impede its normal functioning. They organized watches in order to get some rest. Attempts to mediate failed, as it was clear that all negotiation would have ended in arrest. The protest continued until 15 October. After a six day fast, exhausted they gave up and were subsequently arrested.

For these reasons the three were prosecuted for demolition of state property and resistance to police officers. The prosecutor asked for a prison sentence of one year and eight months for these offences. The lawyers of the three men on the other hand, asked that all be acquitted as they acted out of necessity, i.e., self-defense, and that they be freed.

The single judge court thus proceeded to examine the illegality of detainees actions, the legality of the detention orders, the legality of the conditions of detention and the material conditions for invoking self-defense.

As to the illegality of the protests the three men stated they decided to (join the) protest because they all lived and worked in Italy with their family and because detention conditions were appalling (terrible conditions of hygiene such as mattresses on the floor with no or filthy blankets, having to eat on the floor for lack of chairs and tables, filthy toilets and showers, etc.). All three declared they would rather be in prison, where the detention conditions are far superior, than in the detention center. None of them denied having committed the facts for which they stood accused. Against this background, the Judge decided to examine the legality of the detention measures and conditions in order to assess, in the light of national and supranational sources of law, whether the accused were acting in defense of their fundamental rights ([31], §4).

The judge recalls that Union law is an integral part of the domestic legal order and that there where national law is in conflict with Union law, as is the case with non- or badly transposed directives, the latter has supremacy over the former. More precisely, those provisions that are unconditional and sufficiently clear are self-executing and individuals can avail themselves of these rights before the state. The judge then turns to the El Dridi judgment and argues first of all that the CJEU explicitly established the several steps in the return procedure ranging from the least coercive to the most restrictive measure ([31], §5.1).

The judge then looks at recital 16 and articles 15 and 16 of the Return Directive. According to recital 16 "the purpose of removal should be limited and subject to the principle of proportionality with regard to the means used and objectives pursued" and that detention "is justified only to prepare the return or carry out the removal” if the less coercive measures have failed. Article 15 of the Directive explicitly mentions the strict conditions that apply to detention. The judge then emphasized that a 
detention measure must be "ordered in writing with reasons being given in fact and law" and that the TCN "shall be released immediately if the detention is not lawful" or when a prospect of removal no longer exists. In that respect, he recalled and reviewed the El Dridi judgment ([31], §§5.2-5.5).

In the light of the foregoing, the judge analyses the written detention orders, reminding that not only the national law must comply with Union law, but also the practices of the public administration. Hence, given the fact that the Italian law does not provide for less coercive measure than detention, article 7(3) of the Directive should be applied, which provides for less afflictive alternatives to detention. Furthermore, the written orders must be duly motivated, explaining the particular reasons why in each concrete case it is not possible to apply such less coercive measures. Where this is not the case the detention is unlawful and the TCN has to be released immediately ([31], §5.6).

In the present cases, the judge considered that the written detention orders had not been duly motivated or founded. Consequently, the detention measures were illegitimate. In the case of Aarrassi, the written order stated that "it was not possible to concretely apply less coercive measures", but, notes the judge, it did not give any specific reasons why this was not possible. Thus, the order is not properly motivated and therefore null. The written order provided to Dhifalli has similar deficiencies. It merely stated that he could not be immediately removed and therefore that a detention measure was the most suitable option to secure an effective removal. However, it omitted to specify in this particular case why it was the most suitable option and why other less coercive measures could not be adopted. Hence here too, the judge finds that the detention measure was unlawful. As to Ababsa's situation, the written order justified the detention measure on the alleged danger he represented due to past convictions and the risk of absconding. In fact, he declared to have no permanent residence in Italy. According to the judge, though these motivations were sufficient to deny Ababsa a period for voluntary departure, not the slightest indication was given as to why in this concrete case no less coercive measure could be applied. In fact, the judge notices that according to the expulsion order Ababsa had already been on the Italian territory for fifteen years, implying him being well settled and contradicting the risk of absconding. Furthermore, the risk of absconding by itself does not constitute an to the principle of proportionality. The authorities are thus not exempted from their duty to search for less coercive measures. As to the danger represented by Ababsa, the judge reminds that the Directive provides for a detention measure only so as to assure the effective removal procedure and cannot be grounded on the alleged danger of the person concerned. For all these reasons, this written decision was also considered unlawful ([31], §5.7).

After having reviewed the legality of the detention orders, the judge reviews the legality of its conditions in the light of the case law of the ECtHR and the conditions it laid out: the attainment of a minimum level of severity with regards to the objective circumstances (such as the length of the detention and the severity thereof) and the subjective characteristics of the victim (age, gender, psychological conditions, etc.) ([31], §6.1). According to the judge, both the pictures of the detention center and the direct inspection of the places prove that the accused have been detained in conditions that are "at the limits of decency", not suited to receive human beings. The judge underlines that, though irregular migrants may be used to precarious living conditions, the standards against which the conditions of detention should be gauged are those of the average citizen without distinction as to status, nationality or race. In particular, the judge finds that the level of severity has been reached there where the detainees were obliged (1) to sleep on filthy mattresses, without linen and with equally filthy 
covers; (2) to clean themselves in the poor hygiene conditions: filthy toilets, sinks and towels; (3) to eat without chairs nor tables and receiving too little food to provide the necessary nutrition. These conditions are detrimental to human dignity, especially since the detainees have not been "deprived of their liberty for having committed a crime and that they were compelled to leave their countries of origin in view of improving their situation ([31], §6.2).”

In the light of both the unlawful detention orders and conditions, the judge then examines whether the three detainees, given these breaches of their fundamental rights, had no other choice but to act as they did. The judge reminds that according to Italian case law the essential conditions that constitute self-defense are composed of an unjust aggression and a legitimate reaction. The first criterion has been clearly met, as shown by the violations mentioned above. As to the reaction, it stands without doubt that the rights, liberty and dignity of the detainees were at stake and were being violated at the moment of their protest. As to the proportionality of the protest acts, the defended rights (human dignity and personal liberty) are much more important and valuable than the offended goods such as the prestige of the public administration or state property. It is also obvious that the detainees would not have obtained their release through the use of other means or methods such as a hunger strike, for example. Furthermore, this would require a value judgment, which in a secular state exclusively competes to the acting individual. Lastly, the judge criticizes the dominant attitude of the Italian prosecution according to which the public administration merely applies the law, which provides for detention. This would render any other method futile. In fact, in the case at hand, the detainees had already asked in vain to be released. For all these reasons, the judge finds that the accused acted in self-defense and ordered their immediate release if they were not being held for other-non immigration related—facts ([31], §7).

As revolts in Italian detention centers are frequent, and as Italy has had to amend its immigration law several times since El Dridi, it is no exaggeration to say that this judgment is revolutionary. Besides recognizing the procedural safeguards stipulated by the Directive and its strict interpretation given by the CJEU, the judge not only recognizes the legitimate interest to liberty and human dignity of the detainees, but also of their reasons to immigrate.

In fact, in his analysis of the detention conditions in the light of article 3 ECHR, the judge finds it aggravating that that provision has been violated considering that the detainees have not committed any crime, but simply immigrated in the search for a better life. Furthermore, in assessing the severity of the breach of article 3 , the judge explicitly states that the standards against which the conditions should be gauged are not those of irregular migrants who may be accustomed to precarious living conditions, but against those of is that of the average citizen ([31], §6.2) Therefore, having recognized that they acted out of necessity and self-defense, the Italian judge, having focused on both procedural safeguards and substantive fundamental rights, recognized the actions of the prosecuted as legitimate. Hence, political space and voice has been given where hitherto only further criminalization would have applied.

\subsection{Refusing to Cooperate in Defense of Detained Migrants-The French Cases}

In France too, the reception of the Return Directive has been the subject of much legal discussion. Next to the issue of police custody that was at stake in the Achughbabian case, the issue whether article 16 of the Directive, which spells out the conditions of detention, has direct effect has been much debated. In particular, paragraphs 4 and 5 of that article as they spell out the rights of TCNs to be 
informed of the rules of the detention facilities and to their entitlement to contact relevant and competent organizations, which also have the right to visit such facilities. In this respect, the issue of the direct effect is quite pertinent, as the police officers of these centers have not yet been informed properly on these procedural safeguards. Hence, several appeal courts and the French Court of Cassation have found the detention of TCNs unlawful because of procedural errors [32].

This situation is even more exacerbated as the right of visit of the competent and relevant national and international bodies and organizations (article 16(4) of the Directive) may be made conditional upon authorizations determined by national law. This qualified right is at the core of the case law we discuss below. On the one hand, the authorities claim that due to this conditionality article 16, in particular its fourth paragraph, cannot have direct effect. On the other hand, the competent and relevant associations have united into a platform for the observation of the detention of migrantsObservatoire de l'enferment des étrangers (OEE) — and refuse to receive the authorization to visit as they find the conditions set out by the government to be too restrictive, lacking transparency and impeding their true independent control functions. The OEE criticizes the authorization decree for the fact that the administration has the right to refuse authorizations on the grounds that other associations are present in the center; that each association may only designate five visitors (for the whole of France); that different associations may not access the same detention center on the same day; that the associations must announce their visit twenty four hours in advance; that the decree does not mention the extent of the access to the facilities; and, lastly, they criticize the conflict of interests as the minister of Interiors is in charge of both the management of the detention centers and of the authorizations. They call for, among others, that the authorization be in the hands of an independent body; that the criteria be set out in a law (instead of a decree); that all relevant associations be granted authorization and that access to the whole of the detention facilities be granted [32,33].

The combination of both issues has led the French authorities to be in a permanent breach of article 16 (4) and (5) as there are almost no associations who are authorized and can thus be contacted by the detained TCNs [32,33].

The first cases go back to January 2011. In the light of the direct effect of article 16(5) RD the Juge des libertés et de la détention, i.e., the first judge to review the detention of irregular migrants, annulled the removal order and ordered the release of the TCN as in the administrative files presented before the court there was no indication that the rules of the detention center had been notified [34]. On the same day the same court pronounced a similar judgment, which was appealed. The court of appeal confirmed the release of the detainee on the grounds that the administration had only informed the former of the only organization that is permanently present in the detention center-the Order of Malta-but not of other organizations that could provide assistance if called upon. This irregularity in the procedure entailed that the detention was unlawful [35]. Exactly the same reasoning has become standard case law of the Court of Cassation, which kept rejecting the appeals filed by the administration [36-38].

As the associations of the OEE refuse to ask for authorization under the current decree, the administration finds itself in a dilemma because it cannot provide contact information of several associations though it is required to do so. Hence, the courts find that the rights of normal migrants are not being respected as systematically they are not properly informed [39]. Furthermore, as the RD mentions organizations in the plural, the French courts consider that providing contact information of 
only one authorized organization breaches the safeguards of said directive and thus the rights of the detainees. Hence, the members of the OEE have been able, through their position on the decree, to raise the issue of the rights (thus indirectly of the legitimate interest) of normal migrants. The result of this is that either the detainees have to be released or the authorization conditions brought up to standard. Either way there would be an improvement.

\subsection{Intermediate Conclusions}

The political potential of the Return Directive finds a particular expression in these two cases. The French case displays very formal and procedural reasoning much resembling that of the CJEU. It enabled French migrant defense associations to take a stand against conditions of detention and control thereof they found unacceptable. In the Italian case, both the case law of the ECtHR as that of the Return Directive play an important role, but the judge also explicitly recognizes the legitimate interest of the rioting detained normal migrants. The great impact of the RD on national (case) law is that it has rendered a degree of legal certainty there where hitherto discretionary practices prevailed, and still do [39]. Legal certainty means that norm subjects can calculate both the effects of their own and the administration's actions. This allows them to organize in order to have their legitimate interest recognized, to raise their voice.

\section{Conclusions and Way Forward}

The case law of the Return Directive has been, is and will continue to be of much relevance for the legal position of normal migrants as the principle of proportionality has entered the field of migration. Though only marginally considering the fundamental rights of normal migrants, in applying the principle of proportionality as it has always done, the CJEU has indirectly recognized their legitimate interest to liberty, dignity and maybe even to immigrate. In fact, until now each violation of a Member State examined before the CJEU has led to the liberation of normal migrants and thus de facto to a prolonged stay.

From a more legalistic point of view, through its different cases the CJEU has affirmed the direct effect of many provisions there where Member States had been reluctant to transpose them (properly). More importantly, in the light of the effet utile of the Directive the CJEU gave strict interpretations of these provisions banning more severe state practices that hitherto had been current in many Member States, in particular the use of detention as a first measure in the removal procedure, or the omission of seeking less severe alternatives, but also regarding old orders that still produced their effects as was the case of the re-entry bans.

Yet the most important impact of the Directive and its case law is that, in the light of the principles of sincere cooperation and proportionality, in Member States where old orders that do no longer comply with it but still produce their effects, these actions or omissions have become unlawful and no longer apply. Hence, in many cases this means that normal migrants be released from detention, allowed back into the country and also that the room left for criminalizing illegal immigration has been drastically reduced (from a legal perspective). Throughout the case law this has been the case irrespectively of matters of public order or national security, which are often invoked by Member States in the hope to obtain some exception to the rule of law. 
The combination of these elements has given normal migrants and anyone else supporting their cause a certain degree of legal certainty and as such an extra ground to protest, to raise their voice so as to denounce the injustice of their situation. This is new. However, this novelty is inherent in the relatively recent entry into force of the RD. Member States still have to adjust to it and might even modify it in the future. At any rate, this moment of adjustment has opened opportunities for normal migrants to improve their situation there where Member States had much discretion.

This situation, especially in the examples of the Italian and French judgments discussed above, has clearly interrupted, at least at different intervals, the 'domination' of normal migrants as mere objects of policy with very little to no legal standing and given space to the request to be treated equally, with dignity. In Rancière's words: to test their equality with that of anyone else. The protests in the detention center in Italy, the coordinated action of the French organizations have made it possible to reject the order of things, i.e., the policing of the community, in order to work towards an emancipation of the part without part - the normal migrants. This is clearly a political stake in the meaning given by Rancière and it is inherent to EU immigration policies where the principle of proportionality applies.

Depending on the evolution of the matter in the future, this political moment might be the beginning of more openness toward normal migrants and thus toward equal rights or at least toward equal standards of protection before courts. In that respect, possible improvements have been suggested on the mere basis of the principle of non-discrimination there were "legitimate and appropriate analog[ies]” apply ([4], p. 352).

Just to mention one of the suggested improvements, in civil and criminal matters the right to remain silent and the privilege against self-incrimination apply. This means that the accused has the right not to cooperate. Though this right is not absolute, one cannot be found guilty on the mere fact that one has remained silent or has refused to cooperate. There must always be some other objective evidence to infer guilt. According to the standard case law of the ECtHR ${ }^{4}$ silence on behalf of the accused only corroborates guilt if he or she cannot explain his or her implication against the great amount of evidence acquired independently by the authorities. Yet this is not the case in immigration matters where, as we have seen in the case law of the CJEU, non cooperation or silence is considered a legitimate ground for extending detention or even for criminal imprisonment there where coercive removal has failed. Yet the authorities are capable of finding evidence on the provenance of normal migrants without their cooperation and can initiate a removal procedure without knowing where they came from as they could reach an agreement with a safe third country. Thus, it is hardly only due to lack of cooperation of the normal migrant that a removal procedure fails. Rather, it is due to lack of due diligence or investigative skills on behalf of the authorities. Hence, where such removal fails, there should be no legitimate ground left for (detention in view of) expulsion and criminal detention ([4], pp. 352-56).

4 See ECtHR 25 February 1993, Funke v. France, §44-45; 8 February 1996, John Murray v. the United Kingdom, $\S \S 47-51$. See also ECtHR 17 December 1996, Saunders v. the United Kingdom, §69. The right to remain silent and the privilege against self-incrimination "does not extend to the use in criminal proceedings of material which may be obtained from the accused through the use of compulsory powers but which has an existence independent of the will of the suspect such as, inter alia, documents acquired pursuant to a warrant, breath, blood and urine samples and bodily tissue for the purpose of DNA testing." (Italics added). 
This means that for similar practices of gathering evidence normal migrants are not being treated equally, are being discriminated. In other words, the standards of protection applicable to them are lower than those applied to legal subjects in civil and criminal matters. On what grounds is this justifiable? If such analogies are not being applied today, or if they are regarded as non-applicable, is it not because, as things are today, the normal migrant has no part? Demanding an analogous treatment is a legitimate political act that can be grounded on the principles of law that are applied elsewhere, yet discarded, for no justified reason, when it comes down to immigration matters. These interesting legal challenges seem inevitable and will grow in the future along with the number of normal migrants. Therefore, the question rises whether Member States will continue to be stubborn and remain antipolitical, as Rancière would put it, or whether they will extend the principles and ideals of democracy to anyone within their jurisdiction?

\section{Conflicts of Interest}

The author declares no conflict of interest.

\section{References}

1. Jacques Rancière. La Mésentente. Paris: Galilée, 1995.

2. Jacques Rancière. Disagreement. Minneapolis: Minnesota University Press, 1999.

3. Bas Schotel. On the Right of Exclusion. Abingdon: Routledge, 2012.

4. Andrew Crosby. "Strengthening the Legal Position of Aliens." In Juridische Meesterwerken VUB 2010-2011-Selectie van de Beste Masterproeven in de Rechten. Edited by Alain Francois, Stefaan Smis, Karen Van Laethem, and Guido Van Limberghen. Brussels: Larcier, 2012, pp. 321-67.

5. Catherine Teitgen-Colly. “La détention des étrangers et les droits de l'homme.” In Mondialisation, Migration et Droits de l'Homme: le Droit International en Question, II. Edited by Vincent Chetail. Bruxelles: Bruylant, 2007, pp. 571-618.

6. Hannah Arendt. The Origins of Totalitarianism. San Diego: A Harvest Book, 1973.

7. Louis Henkin. "Human Rights and State 'sovereignty'.” Georgia Journal of International and Comparative Law 25 (1995): 31-45.

8. ECtHR [Plenary]. Cruz Varas and others v. Sweden. Strasbourg, 20 March 1991. http://hudoc.echr.coe.int/sites/eng/pages/search.aspx?i=001-57674.

9. ECtHR [GC]. Chahal v. The United Kingdom. Strasbourg, 15 November 1996. http://hudoc.echr.coe.int/sites/eng/pages/search.aspx?i=001-58004.

10. ECtHR. Jabari v. Turkey. Strasbourg, 11 July 2000. http://hudoc.echr.coe.int/sites/eng/pages/ search.aspx?i=001-58900.

11. ECtHR [GC]. M.S.S. v. Belgium and Greece. Strasbourg, 21 January 2011. http://hudoc.echr.coe.int/sites/eng/pages/search.aspx?i=001-103050.

12. ECtHR. A.A. v. Greece. Strasbourg, 22 July 2010. http://hudoc.echr.coe.int/sites/eng/pages/ search.aspx?i=001-100015.

13. ECtHR. S.D. v. Greece. Strasbourg, 11 June 2009. http://hudoc.echr.coe.int/sites/eng/pages/ search.aspx?i=001-93034. 
14. Gina Clayton. “Asylum Seekers in Europe: M.S.S. v Belgium and Greece.” Human Rights Law Review 11, no. 4 (2011): 758-73.

15. Paul Gragl. “The Shortcomings of Dublin II: Strasbourg's M.S.S. Judgment and Its Implications for the European Union's Legal Order.” In European Yearbook on Human Rights. Edited by Wolfgang B. Benedek, Florence B. R. Benoît-Rohmer, Wolfram K. Karl, and Manfred N. Nowak. Vienna: NWV, 2012, pp. 123-39.

16. Violeta Moreno-Lax. "Dismantling the Dublin System: M.S.S. v. Belgium and Greece.” European Journal of Migration and Law 14 (2012): 1-31.

17. CJEU [GC]. N.S. v. Secretary of State for the Home Department and M.E., A.S.M., M.T., K.P., E.H. v. Refugee Applications Commissioner, Minister for Justice, Equality and Law Reform (joined cases C-411/10 and C-493/10). Luxembourg, 21 December 2011. http://curia.europa.eu/ juris/document/document.jsf?text=\&docid=117187\&pageIndex=0\&doclang=en\&mode=lst\&dir= \&occ=first\&part=1\&cid=723588.

18. CJEU [GC]. Said Shamilovic Kadzoev (Huchbarov) (C-357/09 PPU). Luxembourg, 30 November 2009. http://curia.europa.eu/juris/document/document.jsf?text=\&docid=72526\&pageIndex=0\&do clang $=$ en \&mode $=$ lst \&dir $=\&$ occ $=$ first $\&$ part $=1 \&$ cid $=724013$.

19. CJEU. Hassen El Dridi, alias Karim Soufi (C-61/11 PPU). Luxembourg, 28 April 2011. http://curia.europa.eu/juris/document/document.jsf?text=\&docid=82038\&pageIndex=0\&doclang= en\&mode=lst\&dir=\&occ=first\&part=1\&cid $=724083$.

20. Rosa Raffaelli. "Criminalizing Irregular Immigration and the Returns Directive: An Analysis of the El Dridi Case.” European Journal of Migration and Law 13 (2011): 467-89.

21. CJEU [GC]. Alexandre Achughbabian v. Préfet du Val-de-Marne (C-329/11). Luxembourg, 6 December 2011. http://curia.europa.eu/juris/document/document.jsf?text=\&docid=115941\& pageIndex=0\&doclang=en\&mode=lst\&dir=\&occ=first\&part=1\&cid=724147.

22. Rosa Raffaelli. "Case note: The Achughbabian case: Impact of the Return Directive on national criminal legislation.” Diritto Penale Contemporaneo, 2012. http://ssrn.com/abstract=1998324.

23. CJEU. Md Sagor (C-430/11). Luxembourg, 6 December 2012. http://curia.europa.eu/juris/ document/document.jsf?text=\&docid=131495\&pageIndex=0\&doclang=en\&mode=lst\&dir=\&occ =first\&part=1\&cid=724187.

24. CJEU. Abdoul Khadre Mbaye (C-522/11). Luxembourg, 21 March 2013. http://curia.europa.eu/ juris/document/document.jsf?text=\&docid=135744\&pageIndex=0\&doclang=FR\&mode=lst\&dir= \&occ=first\&part=1\&cid=724323.

25. CJEU. Gjoko Filev, Adnan Osmani (C-297/12). Luxembourg, 19 September 2013. http://curia.europa.eu/juris/document/document.jsf?text=\&docid=141782\&pageIndex=0\&doclang $=$ en\&mode=lst\&dir=\&occ $=$ first $\&$ part $=1 \&$ cid $=724410$.

26. CJEU. Roland Rutili v Ministre de l'intérieur (C-36/75). Luxembourg, 28 October 1975. http://curia.europa.eu/juris/showPdf.jsf?text=\&docid=89064\&pageIndex=0\&doclang=en\&mode= lst\&dir=\&occ=first\&part=1\&cid=724459.

27. CJEU. Régina $v$ Pierre Bouchereau (C-30/77). Luxembourg, 27 October 1977. http://curia.europa.eu/juris/showPdf.jsf?text=\&docid=89572\&pageIndex=0\&doclang=en\&mode= lst\&dir=\&occ=first\&part=1\&cid=724594. 
28. CJEU. Donatella Calfa (C-348/96). Luxembourg, 19 January 1999. http://curia.europa.eu/juris/ document/document.jsf?text=\&docid=44353\&pageIndex=0\&doclang=en\&mode=lst\&dir=\&occ= first\&part=1\&cid=724646.

29. CJEU. Georgios Orfanopoulos, Natascha Orfanopoulos, Melina Orfanopoulos, Sofia Orfanopoulos v. Land Baden-Württemberg and Raffaele Oliveri v. Land Baden-Württemberg (Joined cases C-482/01 and C-493/01). Luxembourg, 29 April 2004. http://curia.europa.eu/juris/ document/document.jsf?text=\&docid=48717\&pageIndex=0\&doclang=en\&mode=lst\&dir=\&occ= first\&part=1\&cid=724693.

30. CJEU [GC]. Commission of the European Communities v. Kingdom of Spain (C-503/03). Luxembourg, 31 January 2006. http://curia.europa.eu/juris/document/document.jsf?text=\&docid= 55480 \&pageIndex=0\&doclang=en\&mode=lst\&dir=\&occ=first\&part=1\&cid=724756.

31. Tribunale di Crotone. n. 1410. 12 December 2012. http://www.penalecontemporaneo.it/upload/ 1357548559crotone.pdf.

32. Serge Slama. "Nouvelle Bataille Judiciaire Autour de l'Information des Étrangers Retenus et le Droit de Visite des ONG Compétentes.” Lettre “Actualités Droits-Libertés” du CREDOF, 2013. http://revdh.files.wordpress.com/2013/03/lettre-adl-du-credof-2-mars-2013.pdf.

33. OEE. Réponse au minister de l'intérieur. Paris, 12 November 2012. http://www.polejuridique.fr/img/OEE_reponse_au_ministre_de_l_interieur_10-11-2012.pdf.

34. TGI Lille, $\mathrm{N}^{\circ}$ 11/00022, 9 January 2011. http://combatsdroitshomme.blog.lemonde.fr/files/2011/ 01/tgi-lille-9-janvier-2011.1295468520.pdf.

35. Cour d'Appel de Douai, $\mathrm{N}^{\circ}$ 11/00013, 11 January 2011. http://combatsdroitshomme.blog. lemonde.fr/files/2011/01/ca-douai-11-janvier-2011-article-16-directive.1294871405.doc.

36. Cour de Cassation. $\mathrm{N}^{\circ}$ 11-30086. 1 February 2012. http://www.legifrance.gouv.fr/ affichJuriJudi.do?oldAction=rechJuriJudi\&idTexte=JURITEXT000025287241\&fastReqId=1295 507372\&fastPos $=1$.

37. Cour de Cassation. $\mathrm{N}^{\circ}$ 11-30091. 23 May 2012. http://www.legifrance.gouv.fr/ affichJuriJudi.do?oldAction=rechJuriJudi\&idTexte=JURITEXT000025923549\&fastReqId=4813 83334\& fastPos=1.

38. Cour de Cassation. $\mathrm{N}^{\circ}$ 11-27271. 13 February 2013. http://www.legifrance.gouv.fr/ affichJuriJudi.do?oldAction=rechJuriJudi\&idTexte=JURITEXT000027073668\&fastReqId=1099 629733\&fastPos $=1$.

39. Andrew Crosby, and Andrea Rea. "Producing undesirables at the border. The uses of discretion at Charles-de-Gaulle airport.” Security Dialogue-The Governance of Border Security in Practice (special issue) (2014): forthcoming.

(C) 2014 by the author; licensee MDPI, Basel, Switzerland. This article is an open access article distributed under the terms and conditions of the Creative Commons Attribution license (http://creativecommons.org/licenses/by/3.0/). 